\title{
Thyroid Hormone-Induced Cytosol-to-Nuclear Translocation of Rat Liver Nrf2 Is Dependent on Kupffer Cell Functioning
}

\author{
Luis A. Videla, ${ }^{1}$ Pamela Cornejo, ${ }^{2}$ Pamela Romanque, ${ }^{1}$ Catherine Santibánez, ${ }^{1}$ Iván Castillo, ${ }^{3}$ \\ and Romina Vargas ${ }^{1}$ \\ ${ }^{1}$ Molecular and Clinical Pharmacology Program, Institute of Biomedical Sciences, Faculty of Medicine, \\ University of Chile, Casilla 70000, Santiago-7, Chile \\ ${ }^{2}$ Faculty of Medicine, Diego Portales University, Santiago, Chile \\ ${ }^{3}$ School of Medicine, Faculty of Medicine, Catholic University of Maule, Talca, Chile
}

Correspondence should be addressed to Luis A. Videla, lvidela@med.uchile.cl

Received 13 October 2011; Accepted 24 November 2011

Academic Editor: Robert B. Petersen

Copyright (C) 2012 Luis A. Videla et al. This is an open access article distributed under the Creative Commons Attribution License, which permits unrestricted use, distribution, and reproduction in any medium, provided the original work is properly cited.

L-3, $3^{\prime}, 5$-triiodothyronine $\left(\mathrm{T}_{3}\right)$ administration upregulates nuclear factor-E2-related factor 2 (Nrf2) in rat liver, which is redoxsensitive transcription factor mediating cytoprotection. In this work, we studied the role of Kupffer cell respiratory burst activity, a process related to reactive oxygen species generation and liver homeostasis, in Nrf2 activation using the macrophage inactivator gadolinium chloride $\left(\mathrm{GdCl}_{3} ; 10 \mathrm{mg} / \mathrm{kg}\right.$ i.v. $72 \mathrm{~h}$ before $\mathrm{T}_{3}[0.1 \mathrm{mg} / \mathrm{kg}$ i.p.]) or NADPH oxidase inhibitor apocynin (1.5 mmol/L added to the drinking water for 7 days before $T_{3}$ ), and determinations were performed $2 \mathrm{~h}$ after $\mathrm{T}_{3} . \mathrm{T}_{3}$ increased nuclear/cytosolic Nrf2 content ratio and levels of heme oxygenase 1 (HO-1), catalytic subunit of glutamate cysteine ligase, and thioredoxin (Western blot) over control values, proteins whose gene transcription is induced by $\mathrm{Nrf} 2$. These changes were suppressed by $\mathrm{GdCl}_{3}$ treatment prior to $\mathrm{T}_{3}$, an agent-eliciting Kupffer-cell depletion, inhibition of colloidal carbon phagocytosis, and the associated respiratory burst activity, with enhancement in nuclear inhibitor of Nrf2 kelch-like ECH-associated protein 1 (Keap1)/Nrf2 content ratios suggesting Nrf2 degradation. Under these conditions, $\mathrm{T}_{3}$-induced tumor necrosis factor- $\alpha$ (TNF- $\alpha$ ) response was eliminated by previous $\mathrm{GdCl}_{3}$ administration. Similar to $\mathrm{GdCl}_{3}$, apocynin given before $\mathrm{T}_{3}$ significantly reduced liver Nrf2 activation and HO1 expression, a NADPH oxidase inhibitor eliciting abolishment of colloidal carbon-induced respiratory burst activity without altering carbon phagocytosis. It is concluded that Kupffer cell functioning is essential for upregulation of liver Nrf2-signaling pathway by $\mathrm{T}_{3}$. This contention is supported by suppression of the respiratory burst activity of Kupffer cells and the associated reactive oxygen species production by $\mathrm{GdCl}_{3}$ or apocynin given prior to $\mathrm{T}_{3}$, thus hindering $\mathrm{Nrf} 2$ activation.

\section{Introduction}

Kupffer cells reside in liver sinusoids representing approximately $35 \%$ of hepatic nonparenchymal cells. These liver macrophages have scavenger receptors that are essential for eliminating blood borne bacteria [1]. In addition, activated Kupffer cells produce and release several mediators including cytokines, lipid substances, and reactive oxygen species (ROS), which can function locally or systemically to mediate immune responses [1]. These responses play a key role in the homeostatic adaptation to liver injury; however, if dysregulated, they can induce acute or chronic liver damage [2-4]. Cytotoxicity of Kupffer cells has been implicated in ischemia-reperfusion (IR) injury, an inflammatory model underlying drastic ROS generation [5], whereas preconditioning strategies against IR injury have been associated with moderate increases in ROS production [6,7].

Thyroid hormone- (L-3,3',5-triiodothyronine, $\mathrm{T}_{3}$ ) induced calorigenic effects involving ROS generation in the liver has been proposed as a preconditioning mechanism for IR injury [8]. $T_{3}$-induced ROS generation occurs at different subcellular sites of hepatocytes and in the respiratory burst of Kupffer cells, triggering the activation of the transcription factors nuclear factor- $\kappa \mathrm{B}(\mathrm{NF}-\kappa \mathrm{B})$, signal transducer and activator of transcription 3 (STAT3), and activating protein 1 (AP-1). Under these conditions, the redox upregulation 
of Kupffer cell-dependent expression of cytokines (tumor necrosis factor- $\alpha$ (TNF- $\alpha$ ), interleukin (IL)-1, and IL-6) is achieved, which upon interaction with specific receptors in hepatocytes trigger the expression of antioxidant enzymes (manganese superoxide dismutase, inducible nitric oxide synthase) $[9,10]$, antiapoptotic proteins ( $\mathrm{Bcl}-2)$ [9], and acute-phase proteins (haptoglobin, $\beta$-fibrinogen) [11]. These responses, and the promotion of hepatocyte and Kupffer cell proliferation observed $[12,13]$, represent cytoprotective effects reestablishing redox homeostasis, promoting cell survival, and protecting the liver against IR injury [7].

Activation of nuclear factor-E2-related factor 2 (Nrf2) also affords cytoprotection, in addition to NF- $\kappa$ B-, STAT3-, and AP-1-dependent signaling pathways, a transcription factor whose cytosol-to-nuclear translocation has been recently found to be triggered by $\mathrm{T}_{3}$ administration through a redox-dependent mechanism [14]. Nrf2 signaling is characterized by its sensitivity to low levels to ROS [15], controls the expression of antioxidant components, detoxification enzymes, membrane transporters, or $26 \mathrm{~S}$ proteasome components, and interplays with NF- $\kappa \mathrm{B}$ affording antiinflammatory responses [16-19]. Thus, the cytoprotective effects of $\mathrm{T}_{3}$-induced liver Nrf2 activation may represent an alternate mechanism for liver preconditioning, a condition associated with Kupffer cell functioning that may constitute a new therapeutic option for liver surgery and liver transplantation in man using reduced-size grafts from living donors $[7,8,20]$. According to these considerations, the purpose of this study was to investigate whether $\mathrm{T}_{3}$-induced liver Nrf2 activation depends on the respiratory burst activity of Kupffer cells, a process related to ROS generation and liver homeostasis. For this purpose, Nrf2 activation, as assessed by cytosol-to-nuclear translocation, was determined in rat liver either without or with pretreatment with the Kupffer cell inactivator gadolinium chloride $\left(\mathrm{GdCl}_{3}\right)$ [21] or with the NADPH oxidase inhibitor apocynin [22] prior to $\mathrm{T}_{3}$. These studies were correlated with the assessment of Kupffer cell functioning by means of colloidal carbon phagocytosis and the respective respiratory burst activity in perfused livers. The expression of the antioxidant proteins heme oxygenase1 (HO-1), catalytic subunit of glutamate cysteine ligase (GCLC), and thioredoxin (Trx) were chosen as prototypical genes controlled by Nrf2 signaling, in addition to the levels of the Nrf2 inhibitor kelch-like $\mathrm{ECH}$-associated protein 1 (Keap1) [17-19].

\section{Methods}

2.1. Animal Treatments. Male Sprague-Dawley rats (Animal Facility of the Institute of Biomedical Sciences, Faculty of Medicine, University of Chile) weighing 180-200 g, housed on a 12-h light/dark cycle, and fed with rat chow and water ad libitum, received a single intraperitoneal dose of $0.1 \mathrm{mg}$ of $\mathrm{T}_{3} / \mathrm{kg}$ body weight or equivalent volumes of the hormone vehicle $0.1 \mathrm{~N} \mathrm{NaOH}$ (controls). Kupffer cells were selectively eliminated by a single intravenous injection of $10 \mathrm{mg}$ of $\mathrm{GdCl}_{3} / \mathrm{kg}$ body weight [21] given $72 \mathrm{~h}$ before $\mathrm{T}_{3}$ administration, and control animals received equivalent volumes of saline. A separate group of rats was given the selective NADPH oxidase inhibitor apocynin $(1.5 \mathrm{mmol} / \mathrm{L})$ added to the drinking water for 7 days prior to $\mathrm{T}_{3}$, a protocol shown to effectively inhibit NADPH oxidase activity in rats [22]. Studies were carried out $2 \mathrm{~h}$ after $\mathrm{T}_{3}$ administration in animals anesthetized with intraperitoneal $(1 \mathrm{~mL} / \mathrm{kg})$ zolazepam chlorhydrate $(25 \mathrm{mg} / \mathrm{mL})$ and tiletamine chlorhydrate $(25 \mathrm{mg} / \mathrm{mL})$ (Zoletil-50; Virbac S/A, Carros, France). In the group of rats subjected to $\mathrm{GdCl}_{3}-\mathrm{T}_{3}$ combined treatment, levels of serum TNF- $\alpha$ were measured by ELISA (UltraSensitive Cytoscreen kit, Biosource International, Camarillo, CA, USA) according to manufacturer's specifications. Experimental animal protocols and animal procedures complied with the Guide for the Care and Use of Laboratory Animals (National Academy of Sciences, NIH Publication 86-23, revised 1985) and were approved by Ethics Committee of the Faculty of Medicine, University of Chile (CBA 0269 FMUCH).

2.2. Kupffer-Cell Inactivation. Liver slices were obtained in anesthetized (Zoletil-50) rats at 24 to $72 \mathrm{~h}$ after- $\mathrm{GdCl}_{3}$, and kinetic changes of ED2-immunolabelled Kupffer cells were determined by immunohistochemistry using a commercial kit (AbD Serotec, Oxford, UK). Briefly, liver samples were fixed in phosphate-buffered formalin (pH 7.4) and incubated with a primary mouse antibody to ED2, followed by incubation with biotin-conjugated secondary goat antibody. Positive reactions were visualized with 3,3'-diaminobenzidine, and results are expressed as the number of cells determined in 10 different $0.7 \mathrm{~mm}^{2}$ areas per liver from 3 rats per timepoint [23].

2.3. Liver Perfusion, Colloidal Carbon Uptake, and CarbonInduced Respiratory Activity. Livers from animals anesthetized with Zoletil-50 were perfused with a solution containing $118 \mathrm{mM} \mathrm{NaCl}, 4.8 \mathrm{mM} \mathrm{KCl}, 1.2 \mathrm{mM} \mathrm{KH}_{2} \mathrm{PO}_{4}$, $1.2 \mathrm{mM} \mathrm{MgSO}_{4}, 2.5 \mathrm{mM} \mathrm{CaCl}_{2}, 25 \mathrm{mM} \mathrm{NaHCO}_{3}$, and $10 \mathrm{mM}$ glucose, equilibrated with and $\mathrm{O}_{2} / \mathrm{CO}_{2}$ mixture $(19: 1, \mathrm{vol} / \mathrm{vol})$ to give $\mathrm{pH} 7.4$, through a cannula placed in the portal vein. Perfusion was carried out at constant flow rates ( 3.5 to $4 \mathrm{~mL} / \mathrm{g}$ liver/min) and temperature (36 to $37^{\circ} \mathrm{C}$ ), without recirculation of the perfusate $[13,24]$. After 15 min equilibration of perfused livers, $\mathrm{O}_{2}$ consumption $\left(\mathrm{QO}_{2}\right)$ was determined in the effluent perfusate collected via a cannula placed in the vena cava and allowed to flow through a Clark-type oxygen electrode. For determination of colloidal carbon uptake by perfused livers, suspensions of India ink (Rotring, Hamburg, Germany) were prepared, dialysed, and infused between 30 to $45 \mathrm{~min}$ of perfusion at the concentration of $0.5 \mathrm{mg} / \mathrm{mL}$. Perfusate samples were taken every $10 \mathrm{~min}$ in the presence and absence of the liver to measure the absorbance of colloidal carbon at $623 \mathrm{~nm}$ [24] (specific extinction coefficient of $0.97[\mathrm{mg} / \mathrm{mL}]^{-1}$ ) [13]. Rates of carbon uptake were calculated from influent minus effluent concentration differences, referred to the perfusion flow. The respiratory burst activity induced by colloidal carbon infusion was assessed by the integration of the area under the $\mathrm{QO}_{2}$ curves between 30 and $45 \mathrm{~min}$, and expressed as $\mu \mathrm{mol} \mathrm{O}_{2} / \mathrm{g}$ liver [13]. These parameters were determined in control rats and in animals after $2 \mathrm{~h}$ of $\mathrm{T}_{3}$ administration 
and pretreatment for $72 \mathrm{~h}$ with $\mathrm{GdCl}_{3}$ or for 7 days with apocynin prior to $\mathrm{T}_{3}$.

2.4. Western Blot Analysis of Nrf2, Keap1, HO-1, GCLC, and Trx. Liver samples (100-500 mg) frozen in liquid nitrogen were homogenized and suspended in a buffer solution $\mathrm{pH} 7.9$ containing $10 \mathrm{mM}$ HEPES, $1 \mathrm{mM}$ EDTA, $0.6 \%$ Nonidet P-40, $150 \mathrm{mM} \mathrm{NaCl}$, and protease inhibitors $(1 \mathrm{mM}$ phenylmethylsulfonyl fluoride, $1 \mu \mathrm{g} / \mathrm{mL}$ aprotinin, $1 \mu \mathrm{g} / \mathrm{mL}$ leupeptin, and $1 \mathrm{mM}$ orthovanadate). Nuclear protein extracts $(100 \mu \mathrm{g})$ and soluble protein fractions $(60 \mu \mathrm{g})$ were mixed with sample loading buffer pH 6.8 (2\% SDS, $0.0625 \mathrm{M}$ Tris, $10 \%$ glycerol, and $2.5 \% \beta$-mercaptoethanol) and heated at $95^{\circ} \mathrm{C}$ for $5 \mathrm{~min}$, separated on $12 \%$ polyacrylamide gels using SDS-PAGE [25], and transferred to nitrocellulose membranes [26], which were blocked for 1 hour at room temperature with TBS-containing $5 \%$ bovine serum albumin. The blots were washed with TBS containing $0.1 \%$ Tween 20 and hybridized with either rabbit polyclonal antibodies for Nrf2, Keap1, HO-1, GCLC, and Trx (Abcam, Cambridge, MA), or mouse monoclonal antibodies for $\beta$-actin (ICN Biomedicals, Inc., Aurora, $\mathrm{OH}$ ) and lamin A/C (BD Transduction Laboratories, San José, CA, USA). In all determinations, anti- $\beta$-actin was used as internal control for cytosolic fractions, whereas antilamin A/C was employed as internal control for nuclear fractions. In addition, the membranes were stained with anti$\alpha$-tubulin or anti-lamin $\mathrm{A} / \mathrm{C}$ to confirm contamination of the cytosolic and nuclear fractions. After extensive washing, the antigen-antibody complexes were detected using horseradish peroxidase goat anti-rabbit IgG or goat anti-mouse IgG and a SuperSignal West Pico Chemiluminescence kit detection system (Pierce, Rockford, IL, USA). Bands were quantified by densitometry using Scion Image (Scion Corp., Frederick, MD).

2.5. Statistics. Data showing Gaussian distribution according to the Kolmogorov-Smirnov test are expressed as means \pm SEM for the number of separate experiments indicated. One-way or two-way ANOVA and the Newman-Keuls' test or Student's $t$-test for unpaired data assessed the statistical significance $(P<0.05)$ of differences between mean values as indicated. All statistical analyses were computed employing GraphPad Prism ${ }^{T M}$ version 2.0 (GraphPad Software Inc., San Diego, CA, USA).

\section{Results}

Administration of the Kupffer cell inactivator $\mathrm{GdCl}_{3}$ to euthyroid rats elicited a decrease in the number of ED2(+) cells, with 95\% $(P<0.05)$ depletion observed at $72 \mathrm{~h}$ (Figure 1(a)), as assessed by immunohistochemical technique with ED2 antibody. Studies using the isolated perfused liver revealed that, at $72 \mathrm{~h}$ after treatment, $\mathrm{GdCl}_{3}$ reduced by $86 \%$ and $83 \%(P<0.05)$ the rate of colloidal carbon uptake (Figure 1(b)) and the associated carbon-induced respiratory activity (Figure $1(\mathrm{c})$ ), respectively, compared to liver perfusions in the absence of carbon infusion. According to these results, the influence of Kupffer cells on $\mathrm{T}_{3}$-induced liver Nrf2 activation was studied by giving $T_{3}$ at the time of maximal ED2(+) Kupffer-cell inactivation $(72 \mathrm{~h}$ after $\mathrm{GdCl}_{3}$ ), and studies on $\mathrm{T}_{3}$ action were carried out $2 \mathrm{~h}$ after $\mathrm{T}_{3}$ administration, time at which $\mathrm{Nrf} 2$ activation is attained [14].

Liver Nrf2 activation induced at $2 \mathrm{~h}$ after $\mathrm{T}_{3}$ administration was evidenced by the significant $24 \%$ decrease in the content of cytosolic Nrf2 (Figure 2(a)) and 434\% enhancement in that of nuclear Nrf2 (Figure 2(b)), with a $463 \%$ increase in nuclear/cytosolic Nrf2 ratio (Figure 2(c)). Treatment with $\mathrm{GdCl}_{3}$ did not significantmodifiy the liver nuclear/cytosolic Nrf2 ratio when given alone (Figure 2(c)). However, cytosolic and nuclear Nrf2 levels after combined $\mathrm{GdCl}_{3}-\mathrm{T}_{3}$ protocol were comparable to control values (Figures 2(a) and 2(b)), leading to a net $91 \%$ decrease $(P<$ $0.05)$ in the nuclear/cytosolic Nrf2 ratio compared to the net effect of $\mathrm{T}_{3}$ alone (Figure 2(c), inset). Under these conditions, upregulation of liver HO-1 (Figure 2(d)), GCLC (Figure 2(e)), and Trx (Figure 2(f)) by $\mathrm{T}_{3}$ was suppressed by the combined $\mathrm{GdCl} 3-\mathrm{T}_{3}$ treatment, without significant effects of $\mathrm{GdCl}_{3}$ when given alone (Figures 2(d), 2(e) and $2(f)$ ). These findings were observed concomitantly with 7.5fold increase in the serum TNF- $\alpha$ levels by $\mathrm{T}_{3}$, with a net $92 \%$ diminution being elicited by the combined $\mathrm{GdCl}_{3}-\mathrm{T}_{3}$ treatment (a) control, $2 \pm 1(n=9)$ pg TNF- $\alpha / \mathrm{mL}$; (b) $\mathrm{T}_{3}, 15 \pm 1(n=3)$; (c) $\mathrm{GdCl}_{3}, 3 \pm 2(n=3)$; (d) $\mathrm{GdCl}_{3}-\mathrm{T}_{3}, 4 \pm 2(n=3)$; (b) versus (a), (c), and (d), $P<0.05)$. Furthermore, liver Nrf2 inhibitor Keap1 levels in the cytosol exhibited $75 \%$ reduction in $\mathrm{T}_{3}$-treated rats over controls (Figure 3(a)), whereas those of nuclear Keap1 were enhanced by $173 \%$ (Figure 3(b)), without significant changes in nuclear Keap1/Nrf2 ratios (Figure 3(c)). Net differences in the latter parameter indicate a substantial enhancement $(P<$ 0.05 ) in animals subjected to combined $\mathrm{GdCl}_{3}-\mathrm{T}_{3}$ treatment $\left[\left(\mathrm{GdCl}_{3}+\mathrm{T}_{3}\right)-\mathrm{GdCl}_{3}\right]$ compared to rats given $\mathrm{T}_{3}$ alone $\left[\mathrm{T}_{3}-\right.$ control] (Figure 3(c), inset).

Administration of apocynin to euthyroid rats resulted in $90 \%$ decrease $(P<0.05)$ in carbon-induced respiratory burst activity assessed in liver perfusion studies (Figure 4(a)), without significant changes in the rate of colloidal carbon uptake (Figure 4(b)). Liver Nrf2 activation by $\mathrm{T}_{3}$ administration involved significant $48 \%$ decrease in the content of cytosolic Nrf2 (Figure 5(a)), 675\% enhancement in nuclear Nrf2 levels (Figure 5(b)), and 14.9-fold increase in nuclear/cytosolic Nrf2 ratio (Figure 5(c)) over control values. Apocynin administration prior to $\mathrm{T}_{3}$ elicited $29 \%$ diminution $(P<0.05)$ in cytosolic Nrf2 (Figure 5(a)), with comparable values of nuclear Nrf2 (Figure 5(b)) and nuclear/cytosolic Nrf2 ratios (Figure 5(c)) to those in rats given apocynin alone, thus eliciting a net $65 \%$ reduction in nuclear/cytosolic Nrf2 ratios (Figure 5(c), inset). Under these conditions, $\mathrm{T}_{3}$-induced upregulation of liver $\mathrm{HO}$ 1 levels was suppressed in apocynin- $\mathrm{T}_{3}$-treated animals (Figure 5(d)).

\section{Discussion}

Kupffer cell functioning assessed in the isolated perfused rat liver by means of colloidal carbon infusion allows the continuous estimation of the associated rate of carbon-particle 


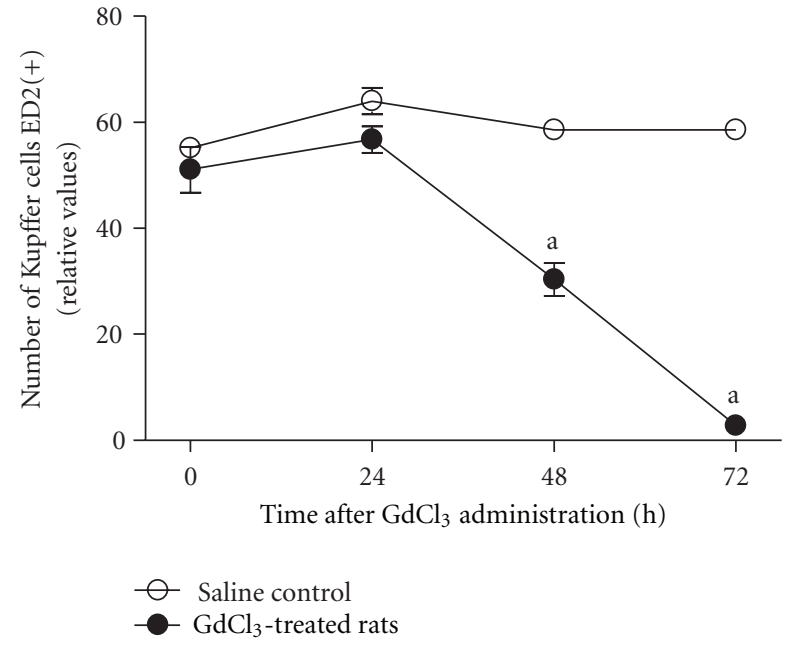

(a)

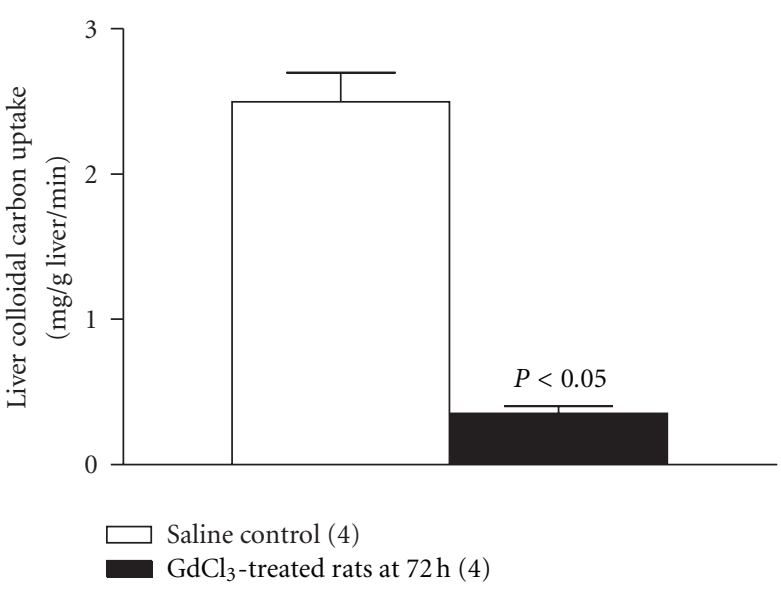

(b)

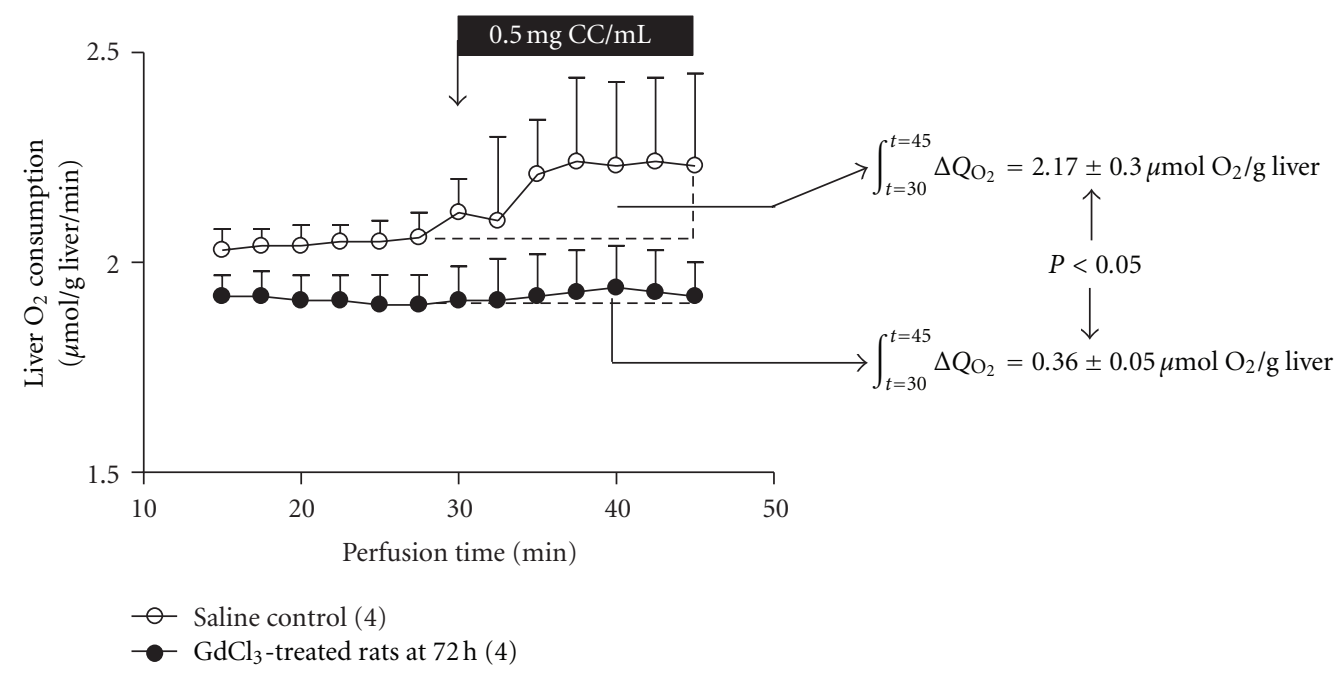

(c)

Figure 1: Gadolinium chloride $\left(\mathrm{GdCl}_{3}\right)$ administration is associated with suppression of Kupffer cell functioning in rat liver. Kinetics of Kupffer cell inactivation after $\mathrm{GdCl}_{3}$ treatment (time zero) in livers from euthyroid rats by immunohistochemistry using ED2 antibody (a), rate of colloidal carbon uptake (b), and carbon-induced liver respiratory activity $\left(\Delta \mathrm{QO}_{2}\right)(\mathrm{c})$ assessed in isolated perfused livers at $72 \mathrm{~h}$ after $\mathrm{GdCl}_{3}$ treatment. $\Delta \mathrm{QO}_{2}$ was calculated by integration of the area under the $\mathrm{O}_{2}$ consumption curves between 30 and 45 min perfusion (c). Values shown represent means \pm SEM for 4 rats per experimental group. ${ }^{a} P<0.05$ versus controls assessed by Student's $t$-test for unpaired data.

phagocytosis and the respiratory burst activity of liver macrophages $[13,24]$. The use of this model system provided evidence for the role of Kupffer cells in the hepatotoxicity of lindane [27], acetaminophen [28], and copper [29], as well as Kupffer cell function adaptation leading to hepatoprotection after $\mathrm{T}_{3}$ administration $[13,20]$. Data reported in this study indicate that $\mathrm{T}_{3}$ administration up-regulates liver Nrf2 signaling depending on Kupffer cell functioning. Early (2 h) liver Nrf2 activation triggered by $\mathrm{T}_{3}$ treatment evidenced by 4.63 -fold enhancement in nuclear/cytosolic Nrf2 ratios denoting cytosol-to-nuclear Nrf2 translocation, occurred without significant changes in nuclear Keap1/Nrf2 ratios. These data indicate that $\mathrm{T}_{3}$ achieves liver Nrf2 upregulation in a time interval at which Nrf2-dependent induction of its inhibitor Keap1 [30] does not occur, resulting in significant increases in the expression of the target genes controlled by Nrf2, namely, HO-1, GCLC, and Trx [18]. $\mathrm{T}_{3}$-induced liver Nrf2 activation involves a redox-dependent mechanism, considering that cytosol to nuclear Nrf2 translocation is blocked by $\mathrm{N}$-acetylcysteine pretreatment [14]. The redox activation of Nrf2 is associated with ROS produced due to acceleration of liver $\mathrm{O}_{2}$ consumption by the calorigenic action of $\mathrm{T}_{3}$ exerted on hepatocytes and Kupffer cells [7], but it also may involve ROS generated in the respiratory burst activity of hepatic macrophages [13]. The latter proposal underlies redox activation of NF- $\kappa \mathrm{B}$ in Kupffer-cell of $\mathrm{T}_{3}$-treated animals [31], with consequent expression and release of TNF- $\alpha$, as reported in this study. Interaction of 

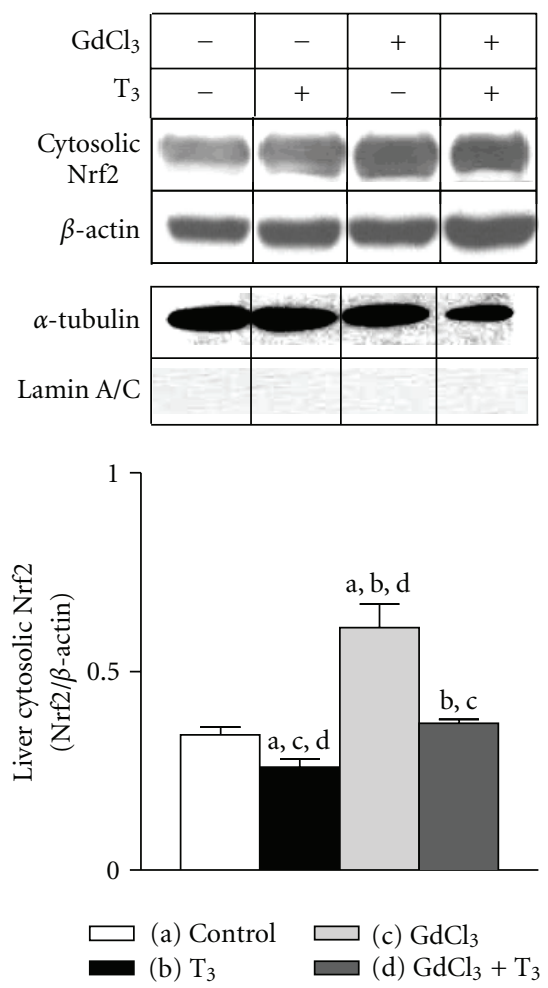

(a)
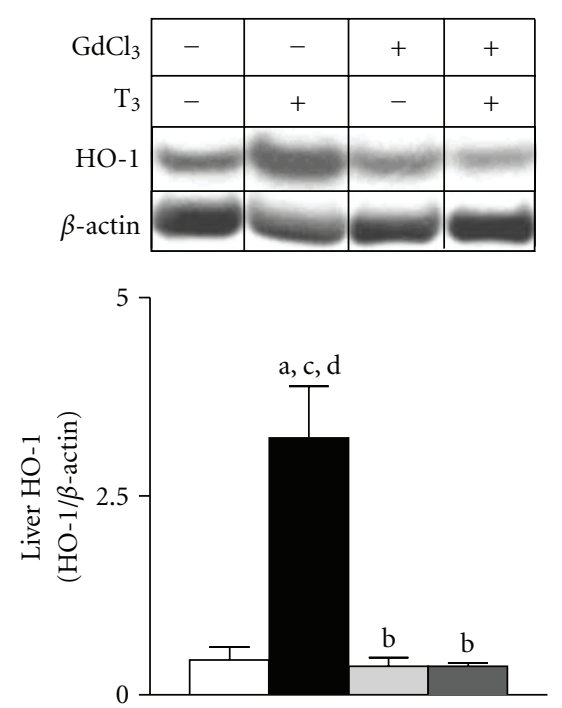

(d)
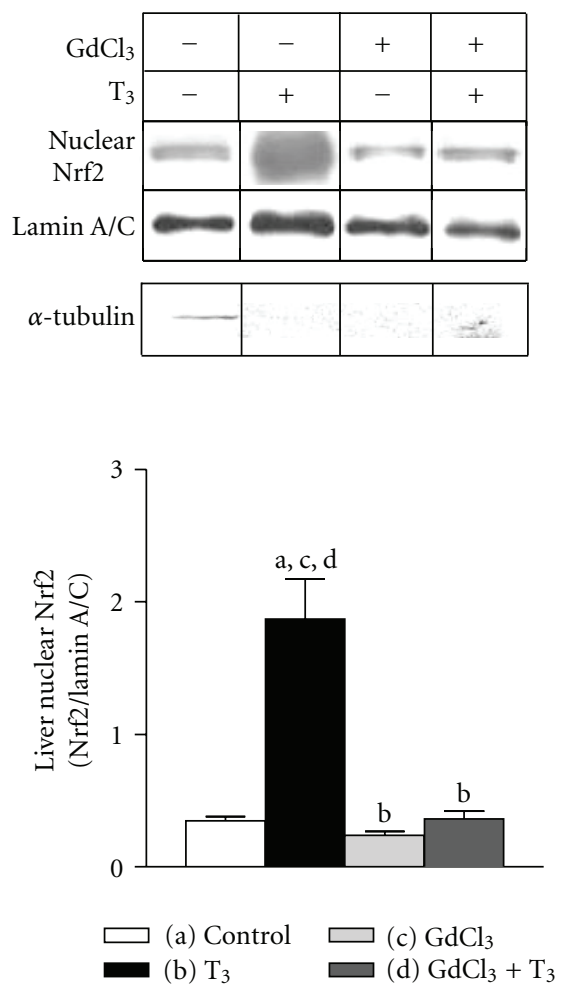

(b)
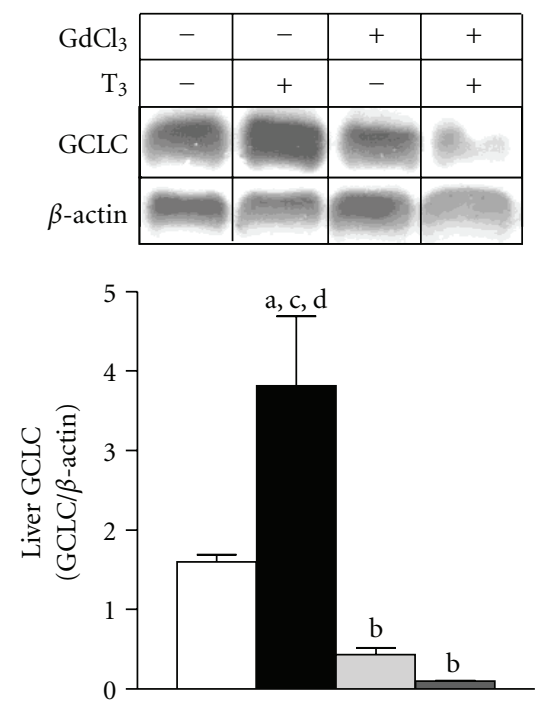

(e)

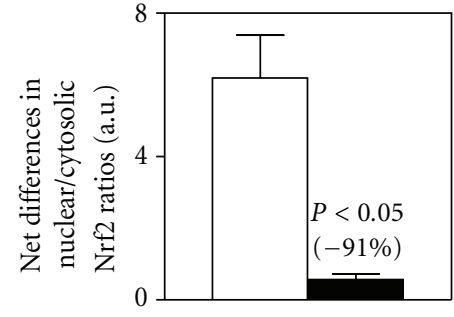

(a) $\mathrm{T}_{3}$-control

(b) $\left(\mathrm{GdCl}_{3}+\mathrm{T}_{3}\right)-\mathrm{GdCl}_{3}$

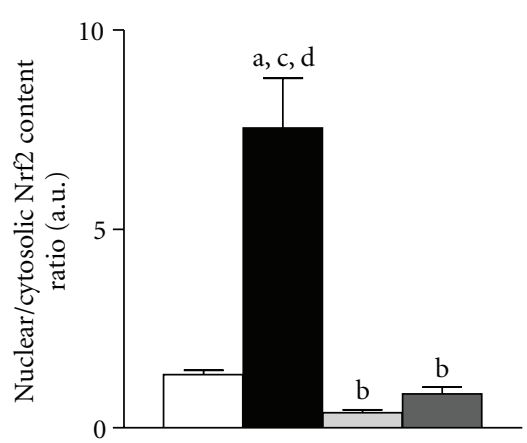

$\square$ (a) Control $\square$ (c) $\mathrm{GdCl}_{3}$ (b) $\mathrm{T}_{3} \square$ (d) $\mathrm{GdCl}_{3}+\mathrm{T}_{3}$

(c)
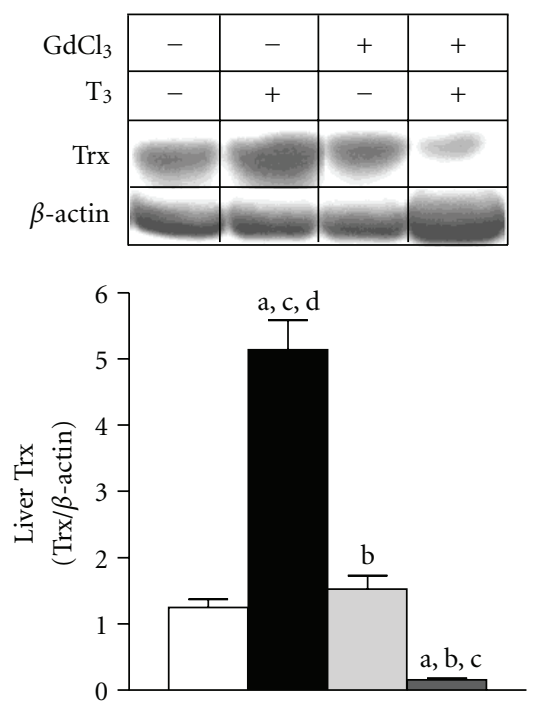

(f)

FIgURE 2: Gadolinium chloride $\left(\mathrm{GdCl}_{3}\right)$ administration is associated with suppression of $\mathrm{T}_{3}$-induced activation of liver Nrf2 signaling. Determinations were performed at $2 \mathrm{~h}$ after $\mathrm{T}_{3}$ administration in rats pretreated with $\mathrm{GdCl}_{3}$ for $72 \mathrm{~h}$. (a) Levels of cytosolic Nrf2 protein $(68 \mathrm{kDa}), \beta$-actin $(43 \mathrm{kDa}), \alpha$-tubulin $(52 \mathrm{kDa})$, and lamin A/C $(65 \mathrm{kDa})$; (b) levels of nuclear Nrf2 protein, lamin A/C, and $\alpha$-tubulin; (c) nuclear/cytosolic Nrf2 content ratios and net effects of $\mathrm{T}_{3}$ and $\mathrm{GdCl}_{3}$ treatments (inset); (d) levels of heme oxygenase 1 (HO-1) protein $(33 \mathrm{kDa})$; (e) levels of catalytic subunit of glutamate cysteine ligase (GCLC) protein $(73 \mathrm{kDa})$; (f) levels of thioredoxin (Trx) protein (12 kDa). Values shown represent means \pm SEM for 3 to 6 rats per experimental group. Significance $(P<0.05$; two-way ANOVA and the NewmanKeuls' test) is indicated by the letters identifying each experimental group. Significance in the inset of (c) was calculated by Student's $t$-test for unpaired data. 


\begin{tabular}{r|c|c|c|c|}
\cline { 2 - 5 } $\mathrm{GdCl}_{3}$ & - & - & + & + \\
\cline { 2 - 5 } $\mathrm{T}_{3}$ & - & + & - & + \\
\hline $\begin{array}{c}\text { Cytosolic } \\
\text { Keap1 } \\
\beta \text {-actin }\end{array}$ & & - & - & \\
\cline { 2 - 5 } & & & & \\
\cline { 2 - 5 } & & & &
\end{tabular}

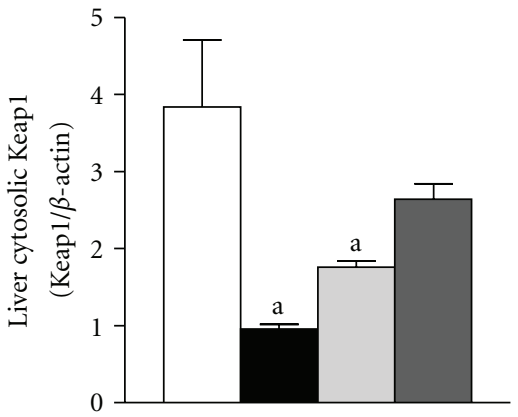

$\begin{array}{ll}\square \text { (a) Control } & \square \text { (c) } \mathrm{GdCl}_{3} \\ \text { (b) } \mathrm{T}_{3} & \square \text { (d) } \mathrm{GdCl}_{3}+\mathrm{T}_{3}\end{array}$

(a)
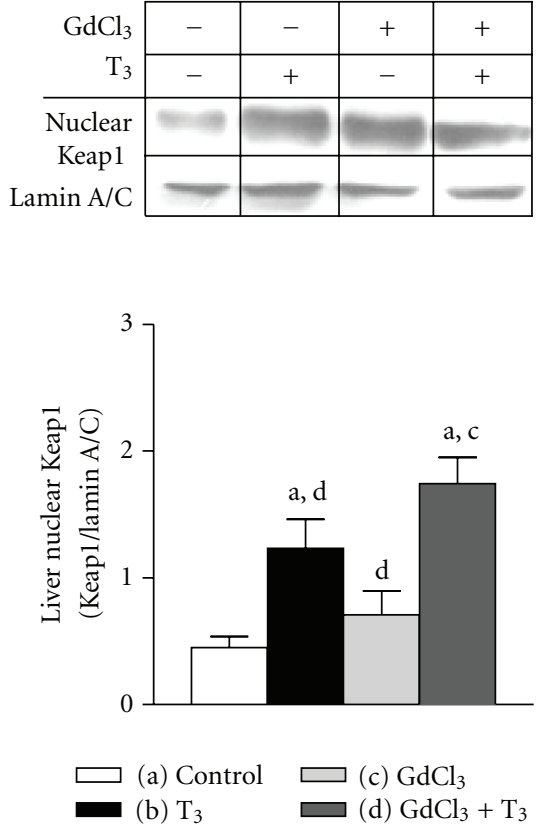

(b)

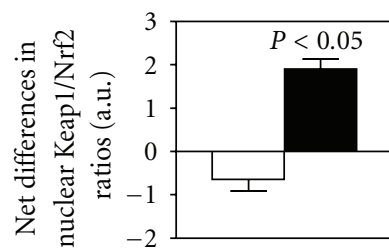

(a) $\mathrm{T}_{3}$-control

(b) $\left(\mathrm{GdCl}_{3}+\mathrm{T}_{3}\right)-\mathrm{GdCl}_{3}$

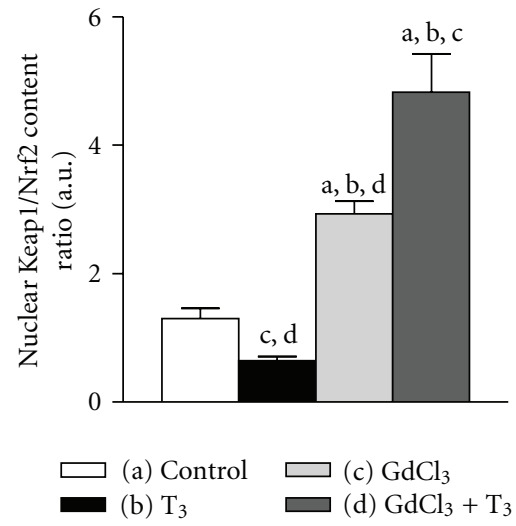

(c)

FIGURE 3: Gadolinium chloride $\left(\mathrm{GdCl}_{3}\right)$ administration is associated with enhancement of liver Keap1/Nrf2 ratios over values in $\mathrm{T}_{3}$-treated rats. Determinations were performed at $2 \mathrm{~h}$ after $\mathrm{T}_{3}$ administration in rats pretreated with $\mathrm{GdCl}_{3}$ for $72 \mathrm{~h}$. (a) Levels of cytosolic Keap1 protein $(70 \mathrm{kDa})$ and $\beta$-actin $(43 \mathrm{kDa})$; (b) levels of nuclear Keap1 protein and lamin A/C (65 kDa); (c) nuclear Keap1/Nrf2 content ratios and net effects of $\mathrm{T}_{3}$ and $\mathrm{GdCl}_{3}$ treatments (inset). Values shown represent means \pm SEM for 4 to 6 rats per experimental group. Significance $(P<0.05$; two-way ANOVA and the Newman-Keuls' test $)$ is indicated by the letters identifying each experimental group. Significance in the inset of (c) was calculated by Student's $t$-test for unpaired data.

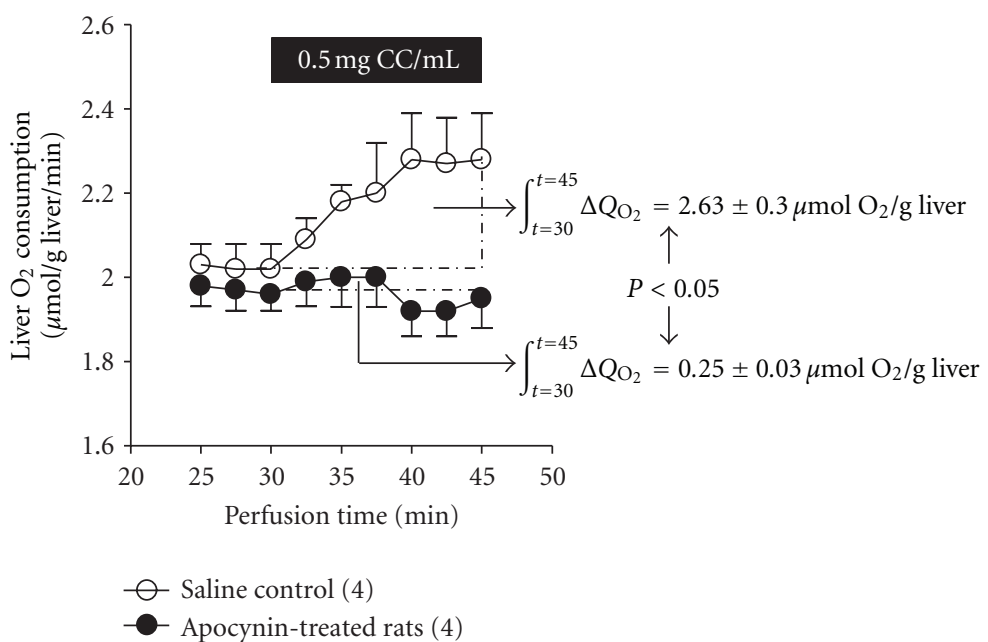

(a)

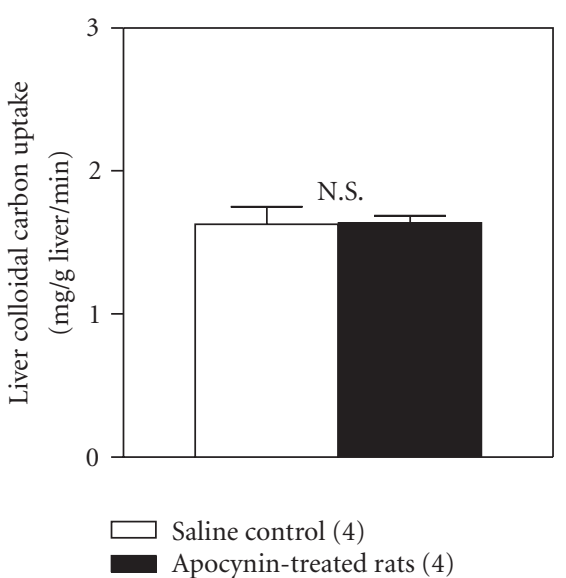

(b)

FIGURE 4: Apocynin administration is associated with suppression of colloidal carbon-induced liver respiratory activity $\left(\Delta \mathrm{QO}_{2}\right)$ assessed in isolated perfused livers from euthyroid rats (a), without altering carbon phagocytosis (b). Determinations were carried out 7 days after apocynin treatment. $\Delta \mathrm{QO}_{2}$ was calculated by integration of the area under the $\mathrm{O}_{2}$ consumption curves between 30 and 45 min perfusion. Values shown represent means \pm SEM for 4 rats per experimental group. Significance $(P<0.05)$ was calculated by Student's $t$-test for unpaired data. 

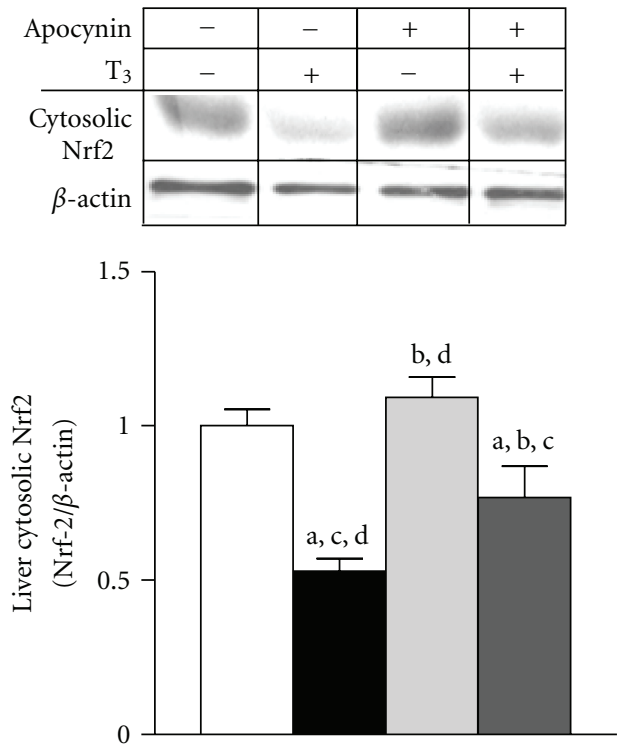

(a) Control

(b) $\mathrm{T}_{3}$

(c) Apocynin

$\square(\mathrm{d})$

(d) Apocynin $+\mathrm{T}_{3}$

(a)
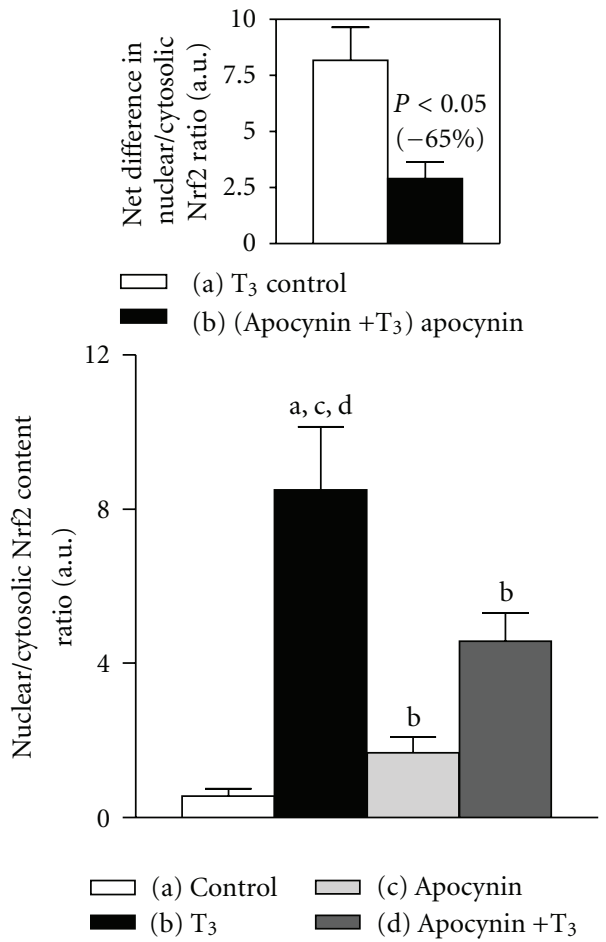

(c)
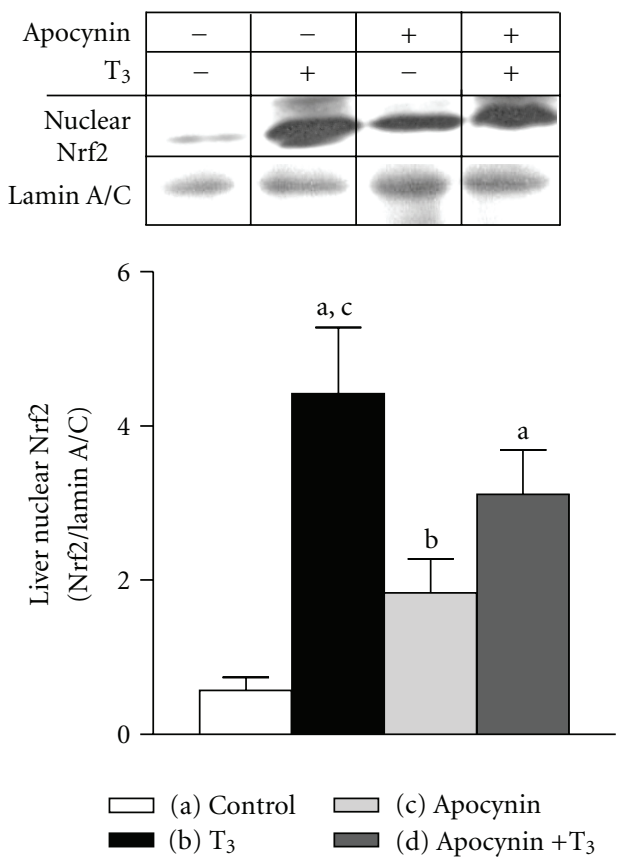

(b)

\begin{tabular}{r|c|c|c|c|}
\cline { 2 - 5 } Apocynin & - & - & + & + \\
\cline { 2 - 5 } $\mathrm{T}_{3}$ & - & + & - & + \\
\hline $\mathrm{HO}-1$ & & & & \\
\cline { 2 - 5 }$\beta$-actin & & & & \\
\cline { 2 - 5 } & & & & \\
\cline { 2 - 5 }
\end{tabular}

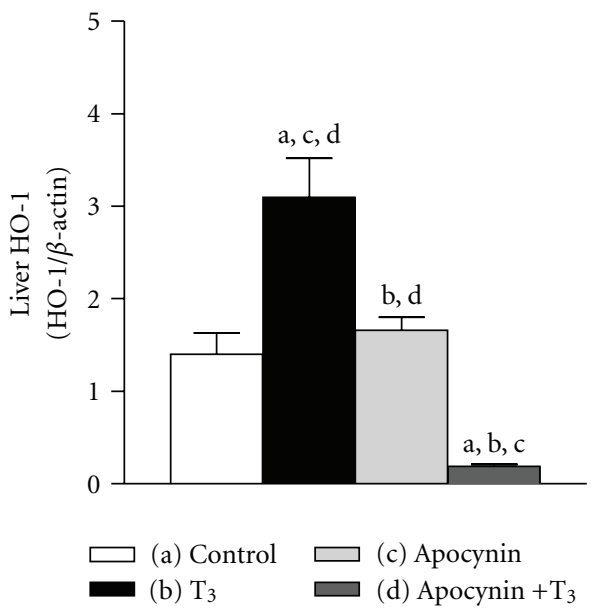

(d)

FIGURE 5: Apocynin administration is associated with diminution of $\mathrm{T}_{3}$-induced activation of liver Nrf2 signaling. Determinations were performed at $2 \mathrm{~h}$ after $\mathrm{T}_{3}$ administration in rats pretreated with apocynin for 7 days. (a) Levels of cytosolic Nrf2 protein (68 kDa) and $\beta$ actin (43 kDa); (b) levels of nuclear Nrf2 protein and lamin A/C (65 kDa); (c) nuclear/cytosolic Nrf2 content ratios and net effects of $\mathrm{T}_{3}$ and apocynin treatments (inset); (d) levels of heme oxygenase $1(\mathrm{HO}-1)$ protein $(33 \mathrm{kDa})$. Values shown represent means \pm SEM for 3 to 4 rats per experimental group. Significance $(P<0.05$; two-way ANOVA and the Newman-Keuls' test) is indicated by the letters identifying each experimental group. Significance in the inset of (c) was calculated by Student's $t$-test for unpaired data. 
TNF- $\alpha$ with TNF- $\alpha$ receptor- 1 in hepatocytes may trigger mitochondrial ROS production [32, 33], reinforcing that achieved by actions of $\mathrm{T}_{3}$ on hepatocyte energy metabolism. Under these conditions, Nrf2 activation may be achieved by direct action of ROS [17-19] or through ROS-dependent formation of cyclopentenone-containing J isoprostanes from polyunsaturated fatty acids, which release Nrf2 upon binding to Keap1 [34, 35]. In addition, increased formation of $\mathrm{Nrf2/c-Jun} \mathrm{complexes} \mathrm{may} \mathrm{occur} \mathrm{due} \mathrm{to} \mathrm{the} \mathrm{ability} \mathrm{of} \mathrm{TNF-} \alpha$ to induce c-Jun nuclear-binding activity [36], heterodimerization that is required for ARE-mediated transcriptional activation [37].

Dependency of $\mathrm{T}_{3}$-induced liver Nrf2 upregulation on Kupffer cells was demonstrated by inactivation of liver macrophages by $\mathrm{GdCl}_{3}$ [21] or inhibition of Kupffer-cell NADPH oxidase activity by apocynin [22, 38]. Administration of the $\mathrm{GdCl}_{3} 72 \mathrm{~h}$ prior to $\mathrm{T}_{3}$ achieved almost complete elimination of ED2(+) cells, a Kupffer cell subpopulation characterized with a ED2 antibody recognizing a membrane antigen of resident macrophages such as Kupffer cells [39, 40]. Liver ED2(+) cells are described as mature macrophages [41], which are mainly located in periportal areas of the liver lobule [42]. These mature liver macrophages have higher lysosomal enzyme activities, phagocytic capacity, and production of TNF- $\alpha$, interleukin-1 and prostaglandin $\mathrm{E}_{2}$ than smaller $\operatorname{ED} 1(+)$ cells located in midzonal and central areas [1], a subpopulation of liver macrophages that is not modified by $\mathrm{GdCl}_{3}$ administration [20]. Under conditions of $\mathrm{GdCl}_{3}$-induced Kupffer-cell depletion, activation of Nrf2 and expression of HO-1, GCLC, and Trx by $\mathrm{T}_{3}$ were abolished, concomitantly with significant enhancement in nuclear Keap1/Nrf2 ratios. The latter finding suggests that the nuclear abundance of Keap 1 is increased by combined $\mathrm{GdCl}_{3}-\mathrm{T}_{3}$ treatment, which may allow an efficient nuclear export mechanism to terminate $\mathrm{T}_{3}$-induced $\mathrm{Nrf} 2$ signaling [43]. In agreement with these views, $\mathrm{T}_{3}$-induced TNF- $\alpha$ response is abolished in rats subjected to combined $\mathrm{GdCl}_{3}$ $\mathrm{T}_{3}$ treatment, which may suppress Kupffer cell-dependent TNF- $\alpha$-induced mitochondrial ROS component, otherwise altering Keap1 to a form which does not have anti-Nrf2 effects [19]. The role of Kupffer cells in $\mathrm{T}_{3}$-induced liver Nrf2 activation suggested by hepatic macrophage depletion after $\mathrm{GdCl}_{3}$ administration is further supported by experiments using apocynin prior to $\mathrm{T}_{3}$. Apocynin inhibits the assembly of the ROS generator NADPH oxidase in neutrophils and macrophages after metabolic conversion, without altering phagocytosis, in addition to its free-radical scavenging properties [38]. In addition, Kupffer cell activation by hepatic IR upregulates kidney Nrf2 signaling to avoid remote organ dysfunction, as treatment with $\mathrm{GdCl}_{3}$ prior to liver IR attenuates the TNF- $\alpha$ response induced, reducing the enhancement in renal levels of the Nrf2 activator 15-deoxy$\Delta^{12,14}$-protaglandin $\mathrm{J}_{2}$, Nrf2 nuclear translocation, and HO-1 expression [34].

\section{Conclusion}

Data presented suggest that Kupffer cell functioning is essential for upregulation of liver Nrf2 stress response-signaling pathway by $\mathrm{T}_{3}$. This is demonstrated by the abolishment of Nrf2 activation and Nrf2-dependent expression of HO-1, GCLC, and Trx by $\mathrm{GdCl}_{3}$-induced Kupffer cell depletion and apocynin inhibition of macrophage NADPH oxidase, when given prior to $\mathrm{T}_{3}$. These agents abrogate the respiratory burst activity of Kupffer cells and the associated ROS production, thus hindering Nrf2 activation. Data presented and the significant diminution in $\mathrm{T}_{3}$-induced changes in hepatic oxidative stress-related parameters by $\mathrm{GdCl}_{3}$ pretreatment, namely, reduced glutathione depletion and enhancement in lipid peroxidation and in the biliary glutathione disulfide release $[13,44]$, point to the crucial role of Kupffer cell functioning in mediating $\mathrm{T}_{3}$-dependent cytoprotection in the liver. This is understood in terms of $\mathrm{T}_{3}$-induced Kupffer cell-dependent development of a suitable prooxidant status in hepatocytes triggering the activation of protective, redoxsensitive transcription factors such as Nrf2, as well as NF- $\kappa \mathrm{B}$, STAT3, and AP-1 [7].

\section{Acknowledgments}

This work was supported by Grant no. 1090020 from FONDECYT, Chile.

\section{References}

[1] M. Bilzer, F. Roggel, and A. L. Gerbes, "Role of Kupffer cells in host defense and liver disease," Liver International, vol. 26, no. 10, pp. 1175-1186, 2006.

[2] H. Jaeschke, "Reactive oxygen and mechanisms of inflammatory liver injury: present concepts," Journal of Gastroenterology and Hepatology, vol. 26, no. 1, pp. 173-179, 2011.

[3] G. Kolios, V. Valatas, and E. Kouroumalis, "Role of Kupffer cells in the pathogenesis of liver disease," World Journal of Gastroenterology, vol. 12, no. 46, pp. 7413-7420, 2006.

[4] H. Tsukamoto, "Redox regulation of cytokine expression in Kupffer cells," Antioxidants and Redox Signaling, vol. 4, no. 5, pp. 741-748, 2002.

[5] H. Jaeschke and A. Farhood, "Neutrophil and Kupffer cellinduced oxidant stress and ischemia-reperfusion injury in rat liver," American Journal of Physiology, vol. 260, no. 3, pp. G355-G362, 1991.

[6] A. Casillas-Ramírez, I. B. Mosbah, F. Ramalho, J. RosellóCatafau, and C. Peralta, "Past and future approaches to ischemia-reperfusion lesion associated with liver transplantation," Life Sciences, vol. 79, no. 20, pp. 1881-1894, 2006.

[7] L. A. Videla, "Hormetic responses of thyroid hormone calorigenesis in the liver: association with oxidative stress," IUBMB Life, vol. 62, no. 6, pp. 460-466, 2010.

[8] V. Fernández, I. Castillo, G. Tapia et al., "Thyroid hormone preconditioning: protection against ischemia-reperfusion liver injury in the rat," Hepatology, vol. 45, no. 1, pp. 170-177, 2007.

[9] V. Fernández, G. Tapia, P. Varela et al., "Redox up-regulated expression of rat liver manganese superoxide dismutase and Bcl-2 by thyroid hormone is associated with inhibitor of $\kappa \mathrm{B}-\alpha$ phosphorylation and nuclear factor- $\kappa \mathrm{B}$ activation," Journal of Endocrinology, vol. 186, no. 3, pp. 539-547, 2005.

[10] V. Fernández, G. Tapia, P. Varela, and L. A. Videla, "Redox regulation of thyroid hormone-induced Kupffer cell-dependent $\mathrm{I} \kappa \mathrm{B}-\alpha$ phosphorylation in relation to inducible nitric oxide synthase expression," Free Radical Research, vol. 39, no. 4, pp. 411-418, 2005. 
[11] G. Tapia, V. Fernández, C. Pino, R. Ardiles, and L. A. Videla, "The acute-phase response of the liver in relation to thyroid hormone-induced redox signaling," Free Radical Biology and Medicine, vol. 40, no. 9, pp. 1628-1635, 2006.

[12] V. Fernández, S. Reyes, S. Bravo et al., "Involvement of Kupffer cell-dependent signaling in $\mathrm{T}_{3}$-induced hepatocyte proliferation in vivo," Biological Chemistry, vol. 388, no. 8, pp. 831-837, 2007.

[13] G. Tapia, I. Pepper, G. Smok, and L. A. Videla, "Kupffer cell function in thyroid hormone-induced liver oxidative stress in the rat," Free Radical Research, vol. 26, no. 3, pp. 267-279, 1997.

[14] P. Romanque, P. Cornejo, S. Valdés, and L. A. Videla, “Thyroid hormone administration induces rat liver Nrf2 activation: suppression by $\mathrm{N}$-acetylcysteine pretreatment," Thyroid, vol. 21, no. 6, pp. 655-662, 2011.

[15] G. Gloire, S. Legrand-Poels, and J. Piette, "NF- $\kappa$ B activation by reactive oxygen species: fifteen years later," Biochemical Pharmacology, vol. 72, no. 11, pp. 1493-1505, 2006.

[16] T. W. Kensler, N. Wakabayashi, and S. Biswal, "Cell survival responses to environmental stresses via the Keap1-Nrf2-ARE pathway," Annual Review of Pharmacology and Toxicology, vol. 47, pp. 89-116, 2007.

[17] M. Kobayashi and M. Yamamoto, "Molecular mechanisms activating the Nrf2-Keap1 pathway of antioxidant gene regulation," Antioxidants and Redox Signaling, vol. 7, no. 3-4, pp. 385-394, 2005.

[18] S. Singh, S. Vrishni, B. K. Singh, I. Rahman, and P. Kakkar, "Nrf2-ARE stress response mechanism: a control point in oxidative stress-mediated dysfunctions and chronic inflammatory diseases," Free Radical Research, vol. 44, no. 11, pp. 1267-1288, 2010.

[19] D. D. Zhang, "Mechanistic studies of the Nrf2-Keap1 signaling pathway," Drug Metabolism Reviews, vol. 38, no. 4, pp. 769789, 2006.

[20] G. Tapia, C. Santibáñez, J. Farías et al., "Kupffer-cell activity is essential for thyroid hormone rat liver preconditioning," Molecular and Cellular Endocrinology, vol. 323, no. 2, pp. 292 297, 2010.

[21] M. J. Hardonk, F. W. J. Dijkhuis, C. E. Hulstaert, and J. Koudstaal, "Heterogeneity of rat liver and spleen macrophages in gadolinium chloride-induced elimination and repopulation," Journal of Leukocyte Biology, vol. 52, no. 3, pp. 296-302, 1992.

[22] J. Gracia-Sancho, B. Laviña, A. Rodríguez-Vilarrupla et al., "Evidence against a role for NADPH oxidase modulating hepatic vascular tone in cirrhosis," Gastroenterology, vol. 133, no. 3, pp. 959-966, 2007.

[23] L. F. Gomes, S. Lorente, K. A. Simon-Giavarotti, K. N. Areco, C. Araújo-Peres, and L. A. Videla, "Tri-iodothyronine differentially induces Kupffer cell ED1/ED2 subpopulations," Molecular Aspects of Medicine, vol. 25, no. 1-2, pp. 183-190, 2004.

[24] K. B. Cowper, R. T. Currin, T. L. Dawson, K. A. Lindert, J. J. Lemasters, and R. G. Thurman, "A new method to monitor Kupffer-cell function continuously in the perfused rat liver," Biochemical Journal, vol. 266, no. 1, pp. 141-147, 1990.

[25] U. K. Laemmli, "Cleavage of structural proteins during the assembly of the head of bacteriophage T4," Nature, vol. 227, no. 5259, pp. 680-685, 1970.

[26] H. Towbin, T. Staehelin, and J. Gordon, "Electrophoretic transfer of proteins from polyacrylamide gels to nitrocellulose sheets: procedure and some applications," Proceedings of the National Academy of Sciences of the United States of America, vol. 76, no. 9, pp. 4350-4354, 1979.
[27] L. A. Videla, P. Troncoso, A. C. M. Arisi, and V. B. C. Junqueira, "Dose-dependent effects of acute lindane treatment on Kupffer cell function assessed in the isolated perfused rat liver," Xenobiotica, vol. 27, no. 7, pp. 747-757, 1997.

[28] G. Tapia, P. Cornejo, J. Ferreira, V. Fernández, and L. A. Videla, "Acetaminophen-induced liver oxidative stress and hepatotoxicity: influence of Kupffer cell activity assessed in the isolated perfused rat liver," Redox Report, vol. 3, no. 4, pp. 213218, 1997.

[29] J. Sans, A. M. Aguilera, P. Faúndez, P. Troncoso, V. Fernández, and L. A. Videla, "Influence of copper-(II) on colloidal carbon-induced Kupffer cell-dependent oxygen uptake in rat liver: relation to hepatotoxicity," Free Radical Research, vol. 30, no. 6, pp. 489-498, 1999.

[30] O. H. Lee, A. K. Jain, V. Papusha, and A. K. Jaiswal, "An autoregulatory loop between stress sensors INrf2 and Nrf2 controls their cellular abundance," Journal of Biological Chemistry, vol. 282, no. 50, pp. 36412-36420, 2007.

[31] G. Tapia, V. Fernández, P. Varela, P. Cornejo, J. Guerrero, and L. A. Videla, "Thyroid hormone-induced oxidative stress triggers nuclear factor- $\kappa \mathrm{B}$ activation and cytokine gene expression in rat liver," Free Radical Biology and Medicine, vol. 35, no. 3, pp. 257-265, 2003.

[32] T. I. Gudz, K. Y. Tserng, and C. L. Hoppel, "Direct inhibition of mitochondrial respiratory chain complex III by cellpermeable ceramide," Journal of Biological Chemistry, vol. 272, no. 39, pp. 24154-24158, 1997.

[33] K. Schulze-Osthoff, A. C. Bakker, B. Vanhaesebroeck, R. Beyaert, W. A. Jacob, and W. Fiers, "Cytotoxic activity of tumor necrosis factor is mediated by early damage of mitochondrial functions. Evidence for the involvement of mitochondrial radical generation," Journal of Biological Chemistry, vol. 267, no. 8, pp. 5317-5323, 1992.

[34] Y. Tanaka, J. M. Maher, C. Chen, and C. D. Klaassen, "Hepatic ischemia-reperfusion induces renal heme oxygenase-1 via NFE2-related factor 2 in rats and mice," Molecular Pharmacology, vol. 71, no. 3, pp. 817-825, 2007.

[35] L. Gao, J. Wang, K. R. Sekhar et al., "Novel n-3 fatty acid oxidation products activate Nrf2 by destabilizing the association between Keap1 and Cullin3," Journal of Biological Chemistry, vol. 282, no. 4, pp. 2529-2537, 2007.

[36] H. Yang, N. Magilnick, X. Ou, and S. C. Lu, "Tumour necrosis factor $\alpha$ induces co-ordinated activation of rat GSH synthetic enzymes via nuclear factor $\kappa \mathrm{B}$ and activator protein1," Biochemical Journal, vol. 391, no. 2, pp. 399-408, 2005.

[37] J. W. Kaspar, S. K. Niture, and A. K. Jaiswal, "Nrf2:INrf2 (Keap1) signaling in oxidative stress," Free Radical Biology and Medicine, vol. 47, no. 9, pp. 1304-1309, 2009.

[38] J. Stefanska and R. Pawliczak, "Apocynin: molecular aptitudes," Mediators of Inflammation, vol. 2008, Article ID 106507, 10 pages, 2008.

[39] J. G. Damoisequx, E. A. Dopp, W. Calame, D. Chao, G. G. MacPherson, and C. D. Dijkstra, "Rat macrophage lysosomal membrane antigen recognized by monoclonal antibody ED1," Immunology, vol. 83, no. 1, pp. 140-147, 1994.

[40] M. Ide, J. Yamate, Y. Machida et al., "Emergence of different macrophage populations in hepatic fibrosis following thioacetamide-induced acute hepatocyte injury in rats," Journal of Comparative Pathology, vol. 128, no. 1, pp. 41-51, 2003.

[41] T. Armbrust and G. Ramadori, "Functional characterization of two different Kupffer cell populations of normal rat liver," Journal of Hepatology, vol. 25, no. 4, pp. 518-528, 1996.

[42] L. Bouwens, M. Baekeland, R. de Zanger, and E. Wisse, "Quantitation, tissue distribution and proliferation kinetics of 
Kupffer cells in normal rat liver," Hepatology, vol. 6, no. 4, pp. 718-722, 1986.

[43] A. K. Jain, D. A. Bloom, and A. K. Jaiswal, "Nuclear import and export signals in control of Nrf2," Journal of Biological Chemistry, vol. 280, no. 32, pp. 29158-29168, 2005.

[44] V. Fernández, L. A. Videla, G. Tapia, and Y. Israel, "Increases in tumor necrosis factor- $\alpha$ in response to thyroid hormoneinduced liver oxidative stress in the rat," Free Radical Research, vol. 36, no. 7, pp. 719-725, 2002. 


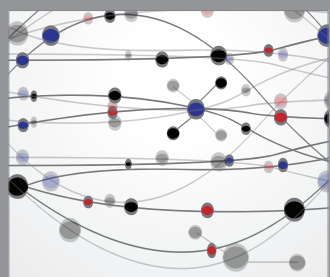

The Scientific World Journal
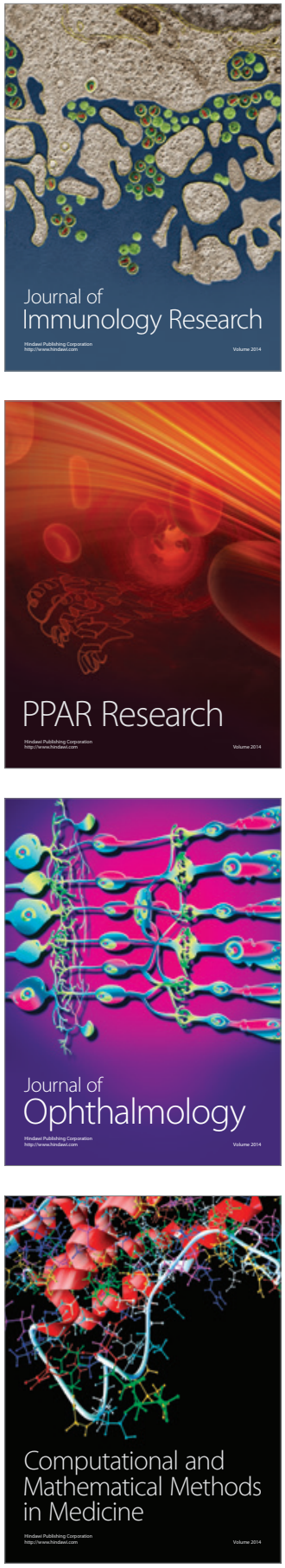

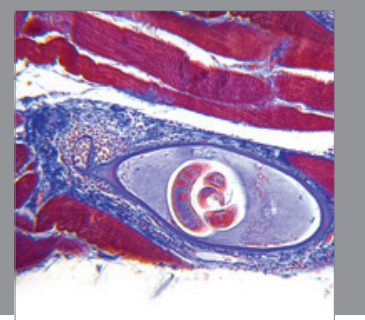

Gastroenterology

Research and Practice
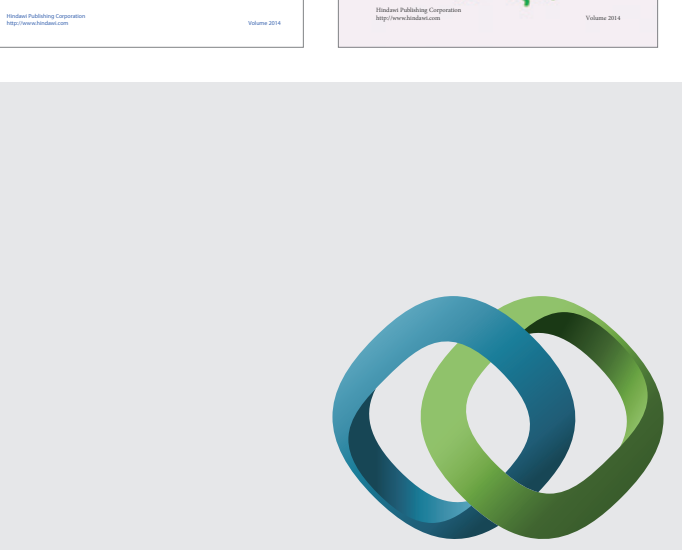

\section{Hindawi}

Submit your manuscripts at

http://www.hindawi.com
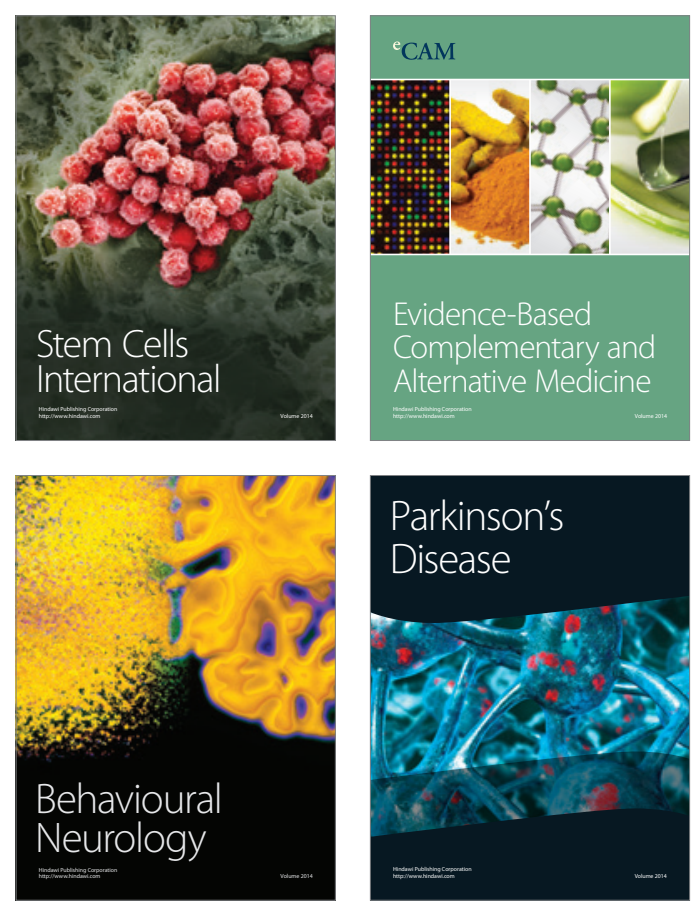

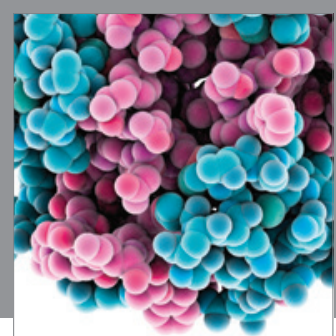

Journal of
Diabetes Research

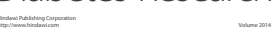

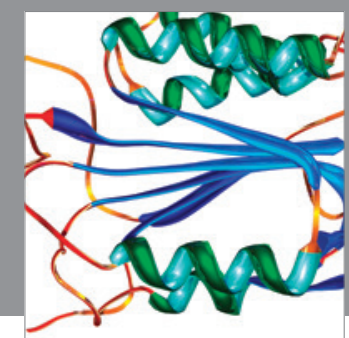

Disease Markers
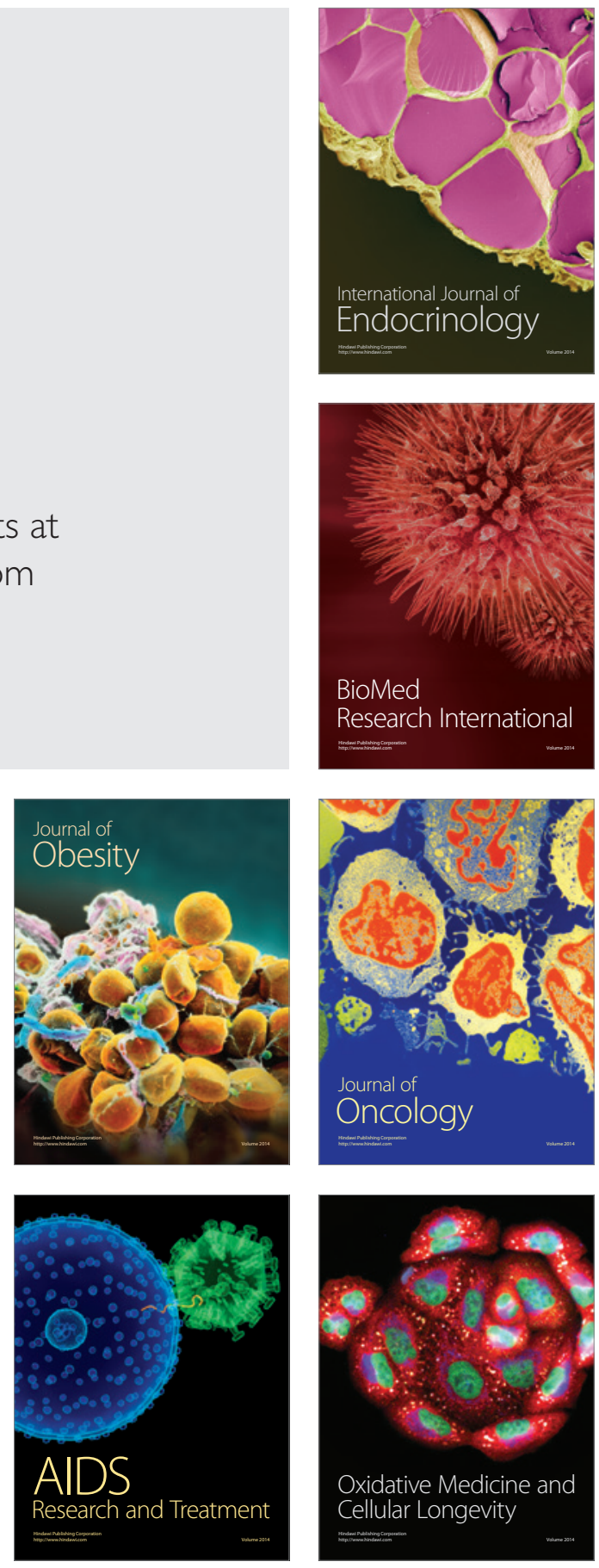